\title{
20. RHYOLITIC AND BASALTIC ASHES FROM THE GALAPAGOS MOUNDS AREA, LEG 70, DEEP SEA DRILLING PROJECT ${ }^{1}$
}

Hans-Ulrich Schmincke, Institut für Mineralogie, Ruhr-Universität, D-4630 Bochum, Federal Republic of Germany

\begin{abstract}
Ashes occurring both as distinct layers and mixed with pelagic sediments of the hydrothermal mounds lying south of the Galapagos Rift are mainly rhyolitic and basaltic. The ashes, of rhyolitic to intermediate composition, appear to belong to a calc-alkalic series and were probably derived from Plinian eruptions in Ecuador or Colombia. Basaltic ashes are made of nonvesicular sideromelane spalling shards and are of tholeiitic composition. They probably were derived locally from fault scarps. Most rhyolitic and basaltic glass shards studied are fresh except for hydration of the rhyolitic shards. Some shards are severely altered, however. Basaltic ash may be more common in pelagic sediments deposited near accretion zones and may be a source of silica and other elements released during diagenesis.
\end{abstract}

\section{INTRODUCTION}

During Leg 70 of the Deep Sea Drilling Project (DSDP) (November-December 1979), 32 holes were drilled at five sites at about $1^{\circ} \mathrm{N}, 86^{\circ} \mathrm{W}$ near the Galapagos Spreading Center (Honnorez et al., 1981) (Figs. 1, 2). Sites 506 to 509 were on or just off hydrothermal mounds, which are low hills 20 to 30 meters high and up to 50 meters in diameter. The mounds generally have Mn-oxide crusts and are rich in green nontronitic clays believed to have formed by the interaction of rising hydrothermal solutions with seawater and pelagic sediments.

The main purpose of Leg 70 was to study the lithology and physical and chemical properties of the hydrothermal mounds and the underlying basement. Hole 510 was drilled on older crust to study basement composition. Volcanic glass was found in a few discrete ash layers (Sites 509 and 510) and dispersed in the pelagic sediment in Holes 506D and 507D. The present chapter describes the shape, color, refractive index (RI), and chemical composition of ten ash samples and briefly discusses their origin and alteration.

\section{METHODS}

Methods to concentrate and clean the volcanic glass and to precisely measure refractive indices are described in Schmincke, 1981. Methods for bulk-rock chemical analyses (XRF, titration, etc.) are described in Flower et al. (in press). The microprobe analyses were carried out with an automated CAMEBAX system, using a 10 to 20 -mm-wide defocussed beam. The agreement between microprobe spot analyses of sideromelane shards and XRF analysis of the purified bulk-glass sample is excellent, including easily volatilized elements such as Na.

\section{DATA}

Eighteen samples, dominantly silty carbonaceous ooze selected from unusual ash abundance in smear slides, were studied initially by examining the insoluble residue of the 63-125 $\mu \mathrm{m}$ fraction under the binocular. Two

\footnotetext{
${ }^{1}$ Cann, J. R., Langseth, M. G., Honnorez, J., Von Herzen, R. P., White, S. M., et al. Init. Repts. DSDP, 69: Washington (U.S. Govt. Printing Office).
}

main types of glass shards were found: basaltic and rhyolitic (Figs. 2, 3; Tables 1-4). These can be easily distinguished from each other by color, size, vesicularity, shape, RI, and chemical composition. Samples that contain rhyolitic shards only are from Holes 510 and the top part of Holes 506D and 507D, whereas all shards in the sample from $507 \mathrm{H}$ are basaltic. Samples from Holes $509,506 \mathrm{D}, 507 \mathrm{~F}$, and the lower two thirds of 507D contain both basaltic and rhyolitic shards and some that are of intermediate composition. Of the 18 samples received, three (506D-4-2, 30-32 cm; 507D-3-2, 58-60 cm; and $509-4-2,66-68 \mathrm{~cm}$ ) may be regarded as distinct ash layers because of the abundance of shards, whereas the remainder contain variable amounts of shards dispersed in nonvolcanic silt. Nine samples were selected for more detailed analysis (Table 1); the remaining nine all contain less than $50 \%$ of glass shards in the insoluble residue of the $63-125 \mu \mathrm{m}$ fraction. Three of these are also shown in Figures 2 and 3.

\section{RHYOLITIC AND INTERMEDIATE SHARDS}

Rhyolitic shards make up more than $90 \%$ of the $63-$ $125 \mu \mathrm{m}$ fraction in Samples 506D-4-2, 30-32 cm; 507D$3-2,58-60 \mathrm{~cm}$; 509-4-2, 66-68 cm; 510-7-5, 50-52 cm and, $55-58 \mathrm{~cm}$; and 510-7-6, 34-36 cm and are less common in five other samples (Fig. 2, Table 1). They are colorless and have mostly platy bubble walls and, less commonly, bubble junctions. Tubular pumice shards are generally present in minor amounts. Refractive indices vary from 1.499 to 1.503 . Shards of higher RI (intermediate composition) dominate in Sample 507D-10$3,20-23 \mathrm{~cm}$, are common in Sample 507D-5-3, 78-80 $\mathrm{cm}$, and occur in accessory amounts in Samples 507F-7$3,74-76 \mathrm{~cm}$ and $510-7-6,34-36 \mathrm{~cm}$. The shards are probably of rhyodacitic to dacitic composition.

Microprobe analyses of shards from four ash samples also indicate rhyolitic composition (Table 2); the silica values are too high as a result of the correction procedures used. Shards from Holes 506D and 509 are very similar in composition but differ from shards from Hole 507D, which is distinctly more fractionated. At least two subpopulations occur in Hole 506D. Ash layers from 


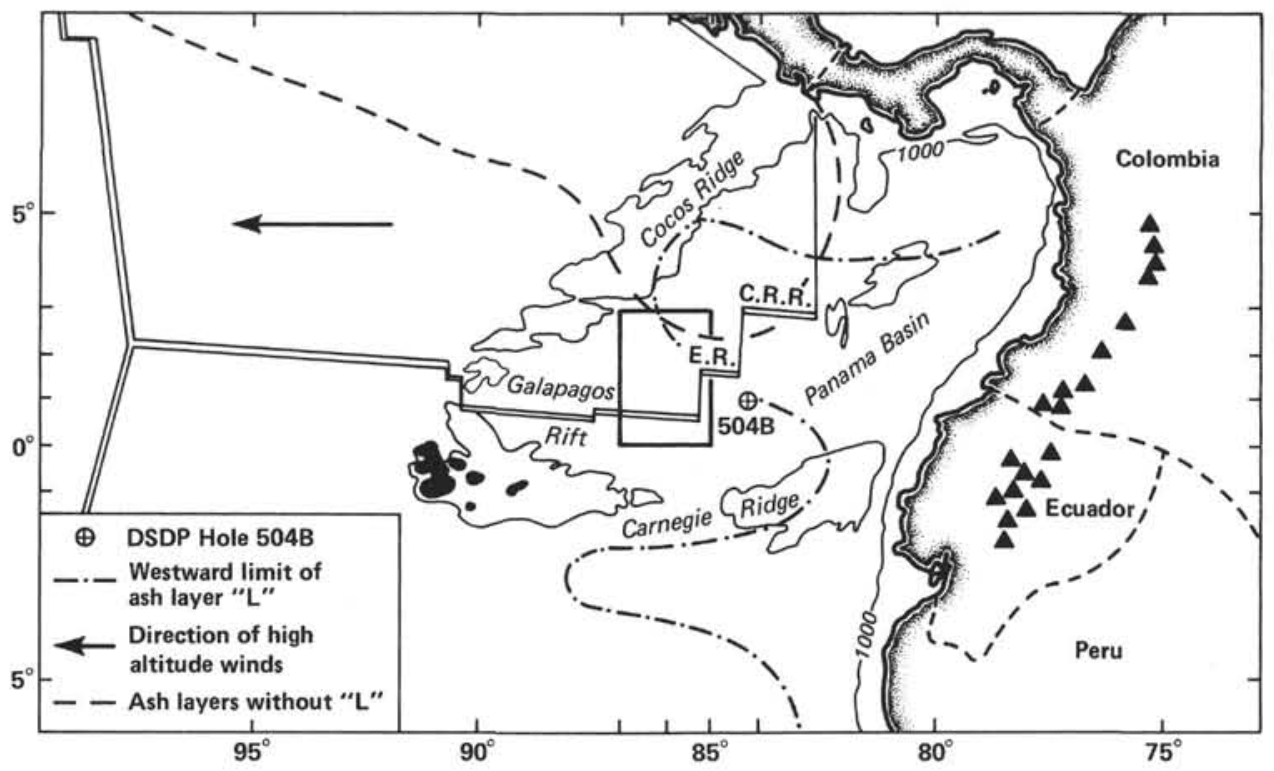

Figure 1. Map of equatorial central Pacific showing the drilling area of Fig. 2 (rectangle). (E.R. = Ecuador Rift. C.R.R. = Costa Rica Rift. Dash-dot lines from Ninkovich and Shackleton [1975]. Dashed line shows area of cores with ash layers (JOIDES Journal, 6(1), 1980, p. 17). Location of deep crustal hole, 504B, also shown.)

Hole 510 differ from those of Holes 506 to 509 not only in their composition (high $\mathrm{Fe}$, low $\mathrm{Ca}, \mathrm{Mg}$ ) but also in the absence of basaltic shards. The ash layers of Hole 510 are also much older (Shipboard Scientific Party, in press a), and the site lies about $125 \mathrm{~km} \mathrm{NNE}$ of the Site 506 to 509 area (Fig. 2).

\section{Discussion}

Honnorez et al. (1981) discount the suggestion of Lonsdale (1977) that prominent reflectors within the area are ash layers because, as they note, "we found only one ash layer in one of our cores" (p. 470). This presumably is the layer at Site 509. The data presented here indicate that ash is more common within the 20- to 30-meter-thick sedimentary section in the mounds area. Among the ash samples analyzed chemically, those from Holes 509 and 506D may possibly be correlative, judging from their similar composition (RI and microprobe), depth in the core, and proximity of the sites. The prominent ash layer at the top of Hole 507D is chemically distinct and younger. If one includes ash deposits studied optically only, there may be at least three distinct ash layers in the mounds area, dominated by rhyolitic to chemically intermediate shards $(507 \mathrm{D}, 509$, two in 506D), as well as about four others farther down in the sections containing only some silicic shards (Hole 507F samples in Table 1 and Sample 507F-5-2, 31-39 $\mathrm{cm}$; Samples 506D-7-1, 133-136 cm and 506D-7-2, 70$72 \mathrm{~cm}$; Sample 507D-5-3, 78-80 cm; and Sample 507D$10-3,20-23 \mathrm{~cm}$ ).

All sites lie in an area west of a belt of Quaternary volcanoes located in Ecuador and Colombia. High-altitude winds blow westward in this area (Fig. 1), suggesting that the ashes are derived from volcanoes situated in the northwestern part of South America. The eruptions responsible for the younger ashes must have occurred in the late Quaternary; based on paleontological evidence, the shards analyzed in Holes 506D and 507D probably are younger than 0.2 m.y. (Shipboard Scientific Party, in press b and c). The source of the Pliocene ashes (2.63 m.y.) at Site 510 is more speculative, but it may have been located in the same general region.

The ash layers occur outside the published limits of the most widespread ash layer " $L$ " in the eastern equatorial Pacific (Fig. 1) collected by piston cores (Bowles et al., 1973; Ninkovich and Shackleton, 1975). The age of ash layer " $\mathrm{L}$ " is assumed to be about $230,000 \mathrm{yr}$. (Bowles et al., 1973; Ninkovich and Shackleton, 1975). Only minor and trace element concentrations were determined by Bowles et al., but the $\mathrm{TiO}_{2}$ concentration of approximately $0.25 \%$ is similar to that of glass shards in Holes 509 and 506D. On the other hand, the bulk composition of shards from ash layer "L," published by Ninkovich and Shackleton (1975), is distinctly more mafic than the microprobe analyses of this study, while the refractive indices (1.498-1.502) are lower than those reported here. Very large Plinian eruptions such as that producing the tephra of layer " $L$ " are likely to have tapped several layers of a zoned magma column, as is generally the case for silicic magma chambers, with the more silicic tephra generally being transported farther than the later more mafic ash. Additional data on the compositions of shards and more precise age determinations of the ash layers occurring in the mounds area are needed before possible correlations with layers such as " $L$ " can be discussed more profitably.

The Galapagos Islands are not a likely source for the layers studied here, because differentiated rocks are very rare and of quartz-trachytic composition (McBirney and Williams, 1969). Moreover, the ash layers should have been deposited westwards of their eruptive source, owing to the prevailing easterly high-altitude wind direc- 


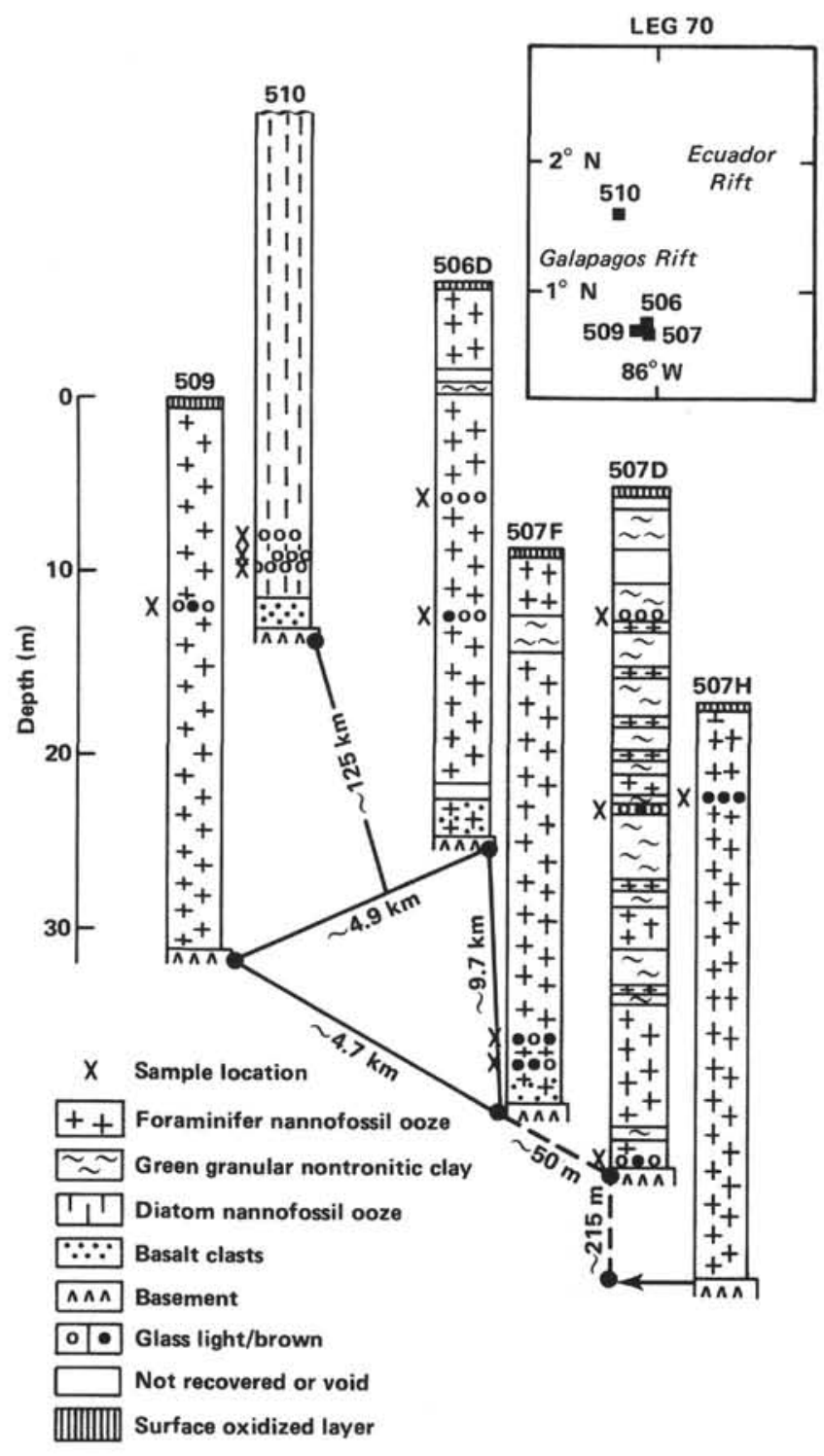

Figure 2. Stratigraphic sections showing position and composition of main ash layers studied and area of drilling.

tions (Ninkovich and Shackleton, 1975). Also, the rhyolites may belong to a calk-alkalic series, further suggesting sources in South or Central America.

Highly radiogenic $\mathrm{Pb}$-isotope compositions were measured in two nontronite samples in Holes 507F and 509B at depths of 4.0 and 3.5 meters (Barrett and Friedrichsen, in press) and were tentatively interpreted as reflecting the replacement of ocean-island derived ash. Data presented here do not exclude such an origin, although derivation of widespread silicic ashes in this area from sources other than in South or Central America seems unlikely. Alteration in the samples studied is not severe enough to generate a clay-rich layer. The surprising freshness of many shards indicates that the $\mathrm{pH}$, chemical composition, and/or time of percolation of the hydrothermal solutions through the ash layers which caused formation of the nontronite clays were generally insufficient to alter the glass pervasively. Derivation of basaltic glass shards from local sources is more plausible, as will be discussed below.

The silicic shards analyzed are reasonably fresh, judging from their isotropic appearance, high totals, and element concentrations. The low totals found, around $95 \%$, are typical of submarine glass shards of rhyolitic composition (Scheidegger et al., 1978). They are interpreted as largely resulting from hydration, accompanied by only minor modification of mobile elements such as $\mathrm{K}$, $\mathrm{Na}, \mathrm{Ca}$, and $\mathrm{Mg}$. Shards in some layers show strong partial dissolution and alteration to an amorphous substance.

\section{BASALTIC ASH}

Basaltic shards make up from $50 \%$ to $99 \%$ in three samples (Samples 507F-7-3, 74-76 cm; 507F-8-1, 56-58 $\mathrm{cm}$; and $507 \mathrm{H}-2-2,27-29 \mathrm{~cm}$ ). The sample from Hole $507 \mathrm{H}$ contains only basaltic shards, while sparse rhyolitic to intermediate shards occur in the Hole 507F samples. Basaltic shards are moderately common or accessory in four other samples from the area but were not found at Site 510. The shards are brown, nonvesicular, and show dominantly curved, blocky to cuneiform shapes. Refractive indices are uniformly around 1.604. Microprobe analyses of shards from two samples (Table 3) show high totals. Moreover, shards in the sample from Hole $507 \mathrm{H}$ were sufficiently abundant to make a very clean concentrate which enabled determination of major and trace elements by $\mathrm{XRF}$, as well as $\mathrm{H}_{2} \mathrm{O}, \mathrm{CO}_{2}$, and $\mathrm{Fe}^{2+}$ determinations. The agreement between the microprobe and whole-rock analysis is remarkably good, with the exception of significantly higher $\mathrm{MnO}_{2}$ in the bulk-glass analysis (Table 3). The composition of the glasses corresponds to low K-MORB. The $\mathrm{SiO}_{2}$ values are slightly too high, as a result of microprobe correction procedures.

\section{Discussion}

The sideromelane shards are tholeiitic in composition and roughly correspond to FETI basalts typical of East Pacific Rise and Galapagos Rift basalts (Natland and Melson, 1980). Shard composition from Cores 7 and 8 (Hole 507F) are practically identical; those from Site 509 are distinctly more mafic (higher $\mathrm{Mg}, \mathrm{Ca}$ ) and lower in $\mathrm{Fe}$ and $\mathrm{Ti}$. The Site 507 compositions reported here are very similar to those obtained on glassy rinds of basalts underlying sediments at Sites 506 to 509 (Natland and Melson, unpubl. data).

The presence of scattered shards of sideromelaneand even of distinct sideromelane ash layers-in pelagic sediments overlying basement poses several problems (see also Scheidegger, 1973; Schmincke, in press).

1) Process of formation. Shards have most likely formed by spalling off glassy pillow rinds or flow tops, as judged by their curved form and the absence of vesicles in the glass. Submarine lava fountaining is another process that may result in especially voluminous sideromelane shard formation because the high ratio of surface area to volume and the small diameter of the resulting minipillows and irregular lava blebs generates both 

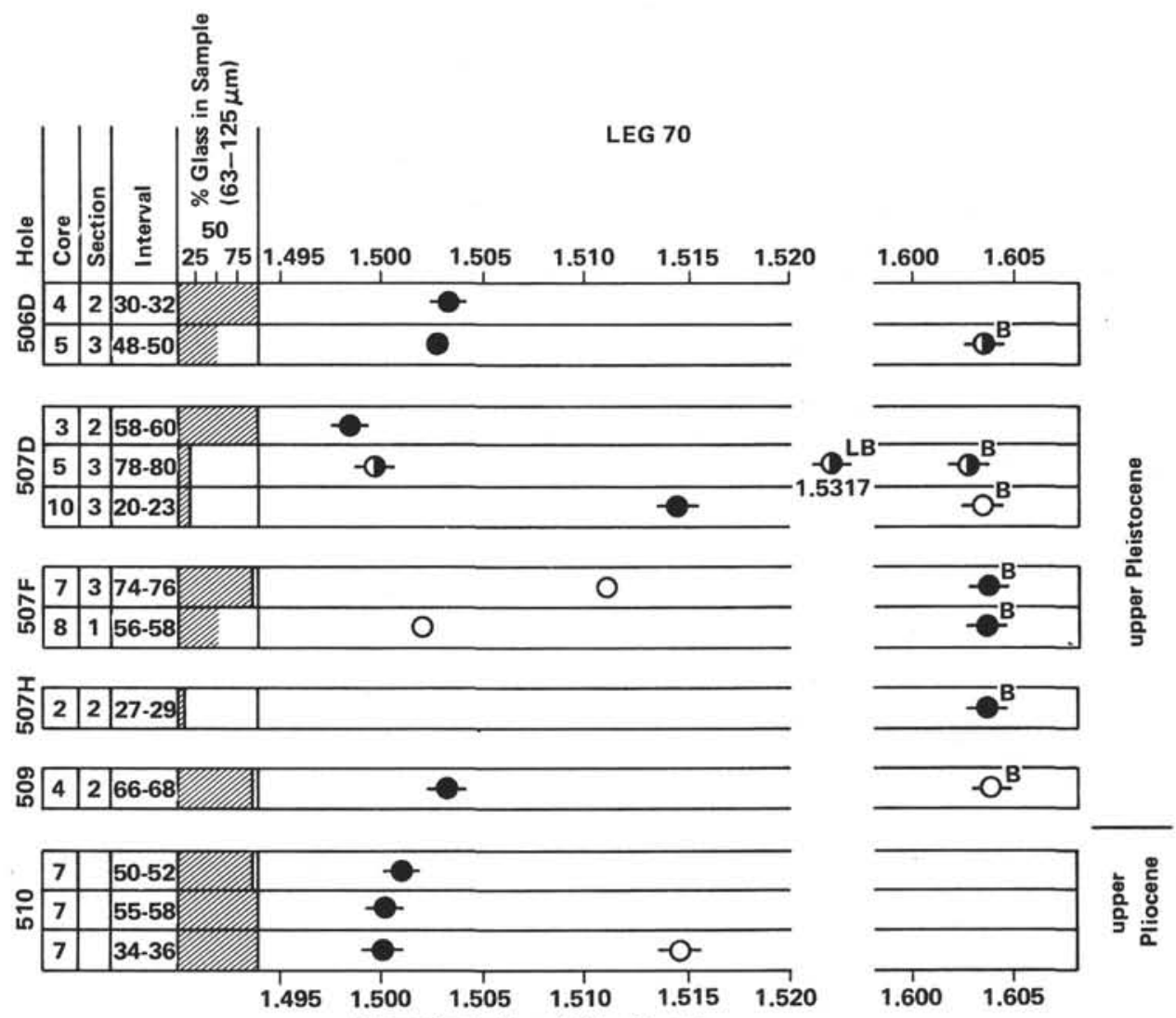

Color

Refractive Index of Glass Shards

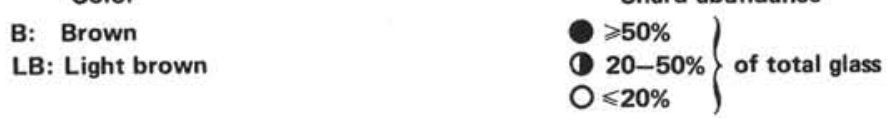

Figure 3. Abundance, color, and refractive indices of shards from ash layers drilled during Leg 70 .

Table 1. Abundance and physical properties of glass shards in ashes from Leg 70.

\begin{tabular}{|c|c|c|c|c|c|c|}
\hline $\begin{array}{c}\text { Sample } \\
\text { (interval in } \mathrm{cm} \text { ) }\end{array}$ & $\begin{array}{l}\text { Sample } \\
\text { Weight } \\
\text { (g) }\end{array}$ & $\begin{array}{l}\text { Insoluble } \\
\text { Residue } \\
\text { (g) }\end{array}$ & $\begin{array}{c}\text { Organic and } \\
\text { Carbonate } \\
\text { Materials } \\
\text { (wt. \%) }\end{array}$ & $\begin{array}{c}\text { Percent } \\
\text { Glass } \\
\text { in } 63-125 \mu \mathrm{m}\end{array}$ & $\begin{array}{l}\text { Refractive } \\
\text { Index }\end{array}$ & $\begin{array}{c}\text { Shape and Color } \\
\text { of Shards }\end{array}$ \\
\hline \multicolumn{7}{|l|}{ Hole 506D } \\
\hline $\begin{array}{l}4-2,30-32 \\
5-3,48-50\end{array}$ & $\begin{array}{l}8.5 \\
5.7\end{array}$ & $\begin{array}{l}6.43 \\
0.68\end{array}$ & $\begin{array}{l}24.4 \\
88.0\end{array}$ & $\begin{array}{l}99 \\
40\end{array}$ & $\begin{array}{l}1.5033 \pm 0.0004 \\
1.5028 \pm 0.0004 \\
1.6036 \pm 0.001\end{array}$ & $\begin{array}{l}\text { bj bw tp, }-, 100 \% \\
\text { bw tp bj, }-, 60 \% \\
\text { spl cs, brown } 40 \%\end{array}$ \\
\hline \multicolumn{7}{|l|}{ Hole 507D } \\
\hline $3-2,58-60$ & 6.0 & 4.78 & 21.0 & 99 & $1.4985 \pm 0.0005$ & bw bj (spl tp),,$- 100 \%$ \\
\hline \multicolumn{7}{|l|}{ Hole 507F } \\
\hline $\begin{array}{l}7-3,74-76 \\
8-1,56-58\end{array}$ & $\begin{array}{r}9.9 \\
12.1\end{array}$ & $\begin{array}{l}4.58 \\
3.73\end{array}$ & $\begin{array}{l}53.7 \\
69.9\end{array}$ & $\begin{array}{l}99 \\
50\end{array}$ & $\begin{array}{l}1.6040 \pm 0.001 \\
1.5110 \pm 0.0003 \\
1.6038 \pm 0.001 \\
1.5021 \pm 0.0003\end{array}$ & $\begin{array}{l}\text { spl cs, brown, } 90 \% \\
\text { bf bw, }-, 10 \% \\
\text { spl cs, brown, } 95 \% \\
\text { bj bw, }-, 5 \%\end{array}$ \\
\hline \multicolumn{7}{|l|}{ Hole 509} \\
\hline $4-2,66-68$ & 17.5 & 13.44 & 23.2 & 95 & $\begin{array}{l}1.5031 \pm 0.0006 \\
1.6035 \pm 0.001\end{array}$ & $\begin{array}{l}\text { bw bj tp rb, }-, 98 \% \\
\text { cs spl, brown, } 2 \%\end{array}$ \\
\hline \multicolumn{7}{|l|}{ Hole 510} \\
\hline $\begin{array}{l}7-5,50-52 \\
7-5,55-58 \\
7-6,34-36\end{array}$ & $\begin{array}{r}7.6 \\
9.3 \\
12.6\end{array}$ & $\begin{array}{l}2.93 \\
4.56 \\
7.40\end{array}$ & $\begin{array}{l}60.9 \\
51.0 \\
41.3\end{array}$ & $\begin{array}{l}95 \\
99 \\
99\end{array}$ & $\begin{array}{l}1.5110 \pm 0.0006 \\
1.5102 \pm 0.0006 \\
1.5100 \pm 0.0004 \\
1.5146 \pm 0.0005\end{array}$ & $\begin{array}{l}\text { bw tp bj, }-, 100 \% \\
\text { bw bj tp, }-, 100 \% \\
\text { bw bj (tp), }-, 99 \% \\
\text { bw rb, }-1 \%\end{array}$ \\
\hline
\end{tabular}


Table 2. Microprobe chemical analyses of rhyolitic glass shards from ashes showing original and recalculated analyses.

\begin{tabular}{|c|c|c|c|c|c|c|c|c|c|c|}
\hline \multirow[b]{3}{*}{$\mathrm{SiO}_{2}$} & \multicolumn{10}{|c|}{$\begin{array}{c}\text { Sample } \\
\text { (interval in } \mathrm{cm} \text { ) }\end{array}$} \\
\hline & \multicolumn{2}{|c|}{$\begin{array}{l}506 \mathrm{D}-4-2 \\
(30-32)^{\mathrm{a}}\end{array}$} & \multicolumn{2}{|c|}{$\begin{array}{l}506 \mathrm{D}-4-2 \\
(30-32)^{\mathrm{b}}\end{array}$} & \multicolumn{2}{|c|}{$\begin{array}{l}509-4-2 \\
(66-68)\end{array}$} & \multicolumn{2}{|c|}{$\begin{array}{l}510-7-5 \\
(50-52)\end{array}$} & \multicolumn{2}{|c|}{$\begin{array}{c}507 \mathrm{D}-3-2 \\
(58-60)\end{array}$} \\
\hline & 72.19 & 75.86 & 71.98 & 77.02 & 72.06 & 75.69 & 70.17 & 74.47 & 75.05 & 78.58 \\
\hline $\mathrm{TiO}_{2}$ & 0.24 & 0.25 & 0.14 & 0.15 & 0.23 & 0.24 & 0.21 & 0.22 & 0.05 & 0.05 \\
\hline $\mathrm{Al}_{2} \mathrm{O}_{3}$ & 13.03 & 13.69 & 12.67 & 13.56 & 13.25 & 13.92 & 11.96 & 12.69 & 11.98 & 12.54 \\
\hline $\mathrm{FeO}^{\circ}{ }^{*}$ & 0.97 & 1.02 & 0.80 & 0.86 & 0.78 & 0.82 & 2.96 & 3.14 & 0.53 & 0.55 \\
\hline $\mathrm{MnO}$ & 0.03 & 0.03 & 0.09 & 0.10 & 0.07 & 0.07 & 0.11 & 0.12 & 0.01 & 0.01 \\
\hline $\mathrm{MgO}$ & 0.22 & 0.23 & 0.26 & 0.28 & 0.19 & 0.20 & 0.04 & 0.04 & 0.09 & 0.09 \\
\hline $\mathrm{CaO}$ & 0.98 & 1.03 & 0.91 & 0.97 & 0.99 & 1.04 & 0.60 & 0.64 & 0.56 & 0.59 \\
\hline $\mathrm{Na}_{2} \mathrm{O}$ & 3.24 & 3.40 & 3.05 & 3.26 & 3.72 & 3.91 & 3.93 & 4.17 & 3.47 & 3.63 \\
\hline $\mathrm{K}_{2} \mathrm{O}$ & 4.21 & 4.42 & 3.51 & 3.76 & 3.91 & 4.11 & 4.24 & 4.50 & 3.77 & 3.95 \\
\hline $\mathrm{P}_{2} \mathrm{O}_{5}$ & 0.04 & 0.04 & 0.05 & 0.05 & 0.00 & 0.00 & 0.01 & 0.01 & 0.00 & 0.00 \\
\hline Total & 95.16 & 100.00 & 93.46 & 100.00 & 95.20 & 100.00 & 94.22 & 100.00 & 95.51 & 100.00 \\
\hline D.I. & 78.27 & & 77.94 & & 76.11 & & 76.13 & & 80.32 & \\
\hline
\end{tabular}

Note: $\mathrm{FeO}^{*}=$ total $\mathrm{Fe}$ as $\mathrm{FeO}$

a Single shard.

b Average of three shards of similar composition.

Table 3. Composition of sideromelane shards from ash layers as determined by microprobe and XRF.

\begin{tabular}{lcccc}
\hline \multicolumn{5}{c}{ Sample } \\
\multicolumn{5}{c}{ (interval in cm) } \\
Component & $507 \mathrm{~F}-7-3$ & $507 \mathrm{~F}-7-3$ & $507 \mathrm{~F}-8-1$ & $509-4-2$ \\
& $(74-76)^{\mathrm{a}}$ & $(74-76)^{\mathrm{b}}$ & $(56-58)$ & $(66-68)$ \\
\hline Major oxides (\%) & & & \\
$\mathrm{SiO}_{2}$ & 51.60 & 51.10 & 51.64 & 52.46 \\
$\mathrm{TiO}_{2}$ & 1.91 & 1.85 & 1.78 & 1.36 \\
$\mathrm{Al}_{2} \mathrm{O}_{3}$ & 13.32 & 13.56 & 13.50 & 13.98 \\
$\mathrm{FeO}^{*}$ & 12.35 & 12.69 & 11.83 & 10.63 \\
$\mathrm{MnO}$ & 0.07 & 0.21 & 0.12 & 0.13 \\
$\mathrm{MgO}$ & 6.90 & 6.96 & 6.99 & 7.56 \\
$\mathrm{CaO}$ & 10.54 & 10.92 & 10.73 & 11.36 \\
$\mathrm{Na} 2 \mathrm{O}$ & 2.45 & 2.32 & 2.36 & 2.23 \\
$\mathrm{~K}_{2} \mathrm{O}$ & 0.08 & 0.07 & 0.07 & 0.03 \\
$\mathrm{P}_{2} \mathrm{O}_{5}$ & 0.15 & 0.16 & 0.11 & 0.08 \\
$\mathrm{H}_{2} \mathrm{O}^{+}$ & - & 0.25 & - & - \\
$\mathrm{CO}$ & - & 0.06 & - & - \\
$\mathrm{Total}$ & 99.37 & 100.15 & 99.13 & 99.82 \\
$\mathrm{Mg}$-value & 53.4 & 52.9 & 54.8 & 59.3 \\
$\mathrm{~S}$ & - & 0.05 & - & - \\
$\mathrm{Cl}$ & - & 0.01 & - & - \\
$\mathrm{O} / \mathrm{S}, \mathrm{Cl}$ & - & 0.03 & - & -
\end{tabular}

Trace elements (ppm)

\begin{tabular}{llrll}
$\mathrm{Cr}$ & - & 150 & - & - \\
$\mathrm{Co}$ & - & 78 & - & - \\
$\mathrm{Ni}$ & - & 78 & - & - \\
$\mathrm{Cu}$ & - & 147 & - & - \\
$\mathrm{Zn}$ & - & 105 & - & - \\
$\mathrm{Rb}$ & - & $<11$ & - & - \\
$\mathrm{Sr}$ & - & 86 & - & - \\
$\mathrm{Y}$ & - & 46 & - & - \\
$\mathrm{Zr}$ & - & 115 & - & - \\
$\mathrm{Nb}$ & - & $<11$ & - & - \\
$\mathrm{Ba}$ & - & 63 & - & - \\
\hline
\end{tabular}

Note: $\mathrm{FeO}^{*}=$ total $\mathrm{Fe}$ as $\mathrm{FeO} . \mathrm{FeO}$ includes $\mathrm{Fe}_{2} \mathrm{O}_{3}=0.36 \%$.

${ }^{a}$ Microprobe analysis.

b XRF analysis. 
Table 4. Characteristic features of deep sea ashes.

\begin{tabular}{|c|c|c|c|c|c|c|c|}
\hline $\begin{array}{l}\text { Refractive } \\
\text { Index }\end{array}$ & Color & $\begin{array}{c}\text { Dominant } \\
\text { Shape }\end{array}$ & Vesicularity & Composition & Structure & Alteration & $\begin{array}{l}\text { Distance from } \\
\text { Source }\end{array}$ \\
\hline $1.49 \sim 1.53$ & Colorless & $\begin{array}{l}\text { Bubble junction, } \\
\text { bubble wall } \\
\text { (platy), pum- } \\
\text { ice shards }\end{array}$ & High & $\begin{array}{l}\text { Rhyolitic to } \\
\text { rhyodacitic }\end{array}$ & $\begin{array}{l}\text { Discrete ash layers } \\
\text { with sharp base } \\
\text { and gradational } \\
\text { top; dispersed } \\
\text { in turbidites }\end{array}$ & $\begin{array}{l}\text { Hydration } \\
\text { dissolution; } \\
\text { zeolitization }\end{array}$ & $\begin{array}{l}\text { Tens to hundreds } \\
\text { of } \mathrm{km}\end{array}$ \\
\hline$\sim 153-\sim 1.56$ & $\begin{array}{c}\text { Light brown } \\
\text { to green }\end{array}$ & $\begin{array}{l}\text { Bubble junction, } \\
\text { bubble wall } \\
\text { (platy), pum- } \\
\text { ice shards }\end{array}$ & $\begin{array}{l}\text { High to mod- } \\
\text { erate }\end{array}$ & $\begin{array}{l}\text { Dacite to } \\
\text { andesite; } \\
\text { tephrite }\end{array}$ & $\begin{array}{l}\text { Discrete ash layers } \\
\text { with sharp base } \\
\text { and gradational } \\
\text { top; dispersed } \\
\text { in turbidites }\end{array}$ & & $\begin{array}{l}\text { Tens to hundreds } \\
\text { of } \mathrm{km}\end{array}$ \\
\hline$\sim 1.56--1.61$ & Brown & $\begin{array}{l}\text { Blocky to cunei- } \\
\text { form (non- } \\
\text { vesicular) to } \\
\text { irregular } \\
\text { (vesicular } \\
\text { shards) }\end{array}$ & $\begin{array}{l}\text { Low to absent } \\
\text { in deep sea } \\
\text { environment; } \\
\text { vesicular near } \\
\text { sea mounts } \\
\text { or islands }\end{array}$ & $\begin{array}{l}\text { Basaltic an- } \\
\text { desite to } \\
\text { basalt }\end{array}$ & $\begin{array}{l}\text { Typically dis- } \\
\text { persed; discrete } \\
\text { layers near } \\
\text { mid-ocean } \\
\text { ridges, sea } \\
\text { mounts, or } \\
\text { islands }\end{array}$ & $\begin{array}{l}\text { Partial to complete } \\
\text { palagonitiza- } \\
\text { tion; local dis- } \\
\text { solution smec- } \\
\text { titization; zeo- } \\
\text { litization }\end{array}$ & $\begin{array}{l}\text { Generally meters to } \\
\text { kilometers } \\
\text { except near } \\
\text { islands }\end{array}$ \\
\hline
\end{tabular}

abundant glass and a clastic deposit from which small shards may become separated (Schmincke et al., 1978).

2) Site of formation. The fact that ash layers composed largely or entirely of sideromelane occur interbedded with pelagic sediment some $\mathbf{2 0}$ meters or more above basement suggests off-axis volcanism that occurred long after formation of crust at the ridge axis or derivation from axis basalt sequences exposed to submarine erosion along fault scarps and/or upward transport by bioturbation.

The absence of any constructional feature in the area that might indicate young volcanism (Lonsdale, 1977) is a major argument against off-axis volcanism, however. The area of hydrothermal mounds has been surveyed in detail by Lonsdale (1977) using deep-towed instruments. The main fault scarp in the general area is located $17 \mathrm{~km}$ south of the Galapagos Rift, about $7 \mathrm{~km}$ north of Site 507 , but it is north-facing. It is sediment covered just north of Site 507 but has bare basalt exposures about 5 $\mathrm{km}$ south, about $10 \mathrm{~km}$ from Site 507 . The smaller faults at 24 and $26 \mathrm{~km}$ south of the Rift are dominantly sediment covered. It is one of the characteristic features of the area that, as a result of the high productivity of surface waters above the Panama Basin, the sedimentation rate of pelagic ooze is about $50 \mathrm{~m} / \mathrm{m} . \mathrm{y}$. (Lonsdale, 1977). The occurrence of pure sideromelane shards at Site $507 \mathrm{H}, 5.4$ meters below the surface suggests deposition of the ash probably less than $0.1 \mathrm{~m}$.y. ago. It is likely that a larger part of the north fault was exposed at that time, but the distance of some $7 \mathrm{~km}$ is still quite far. Major bare fault scarps may occur in the unsurveyed area east of Site 507, but this is speculative.

Microprobe analyses of six different sideromelane shards from Hole 507F gave identical results which, moreover, agree with the analysis of the bulk sample (Table 3). Such chemical homogeneity is surprising, since lavas studied from the nearby Galapagos Rift and at Leg 54 and Leg 70 sites show a wide range in basaltic composition (Natland and Melson, 1980; Natland, 1980), but chemical homogeneity in sideromelane shard populations has been noted in previous studies of similar deposits interbedded with pillow lavas or with sediments. It indicates that the shards were derived from a locally restricted source.
Transport of shards by bottom currents from the accretion zone or distant basement scarps is unlikely, because this would almost certainly result in chemically heterogeneous populations. Moreover, deep-tow observations do not indicate the existence of bottom currents capable of such transport (e.g., Lonsdale, 1977).

3) Glass shards as sources of elements released during diagenesis of hydrothermal activity. The fact that basaltic glass shards evidently derived from nearby sources occur intermixed with shards of rhyolitic composition derived from land volcanoes more than $500 \mathrm{~km}$ away from the drill sites suggests that sideromelane shards may be more common in this environment than generally thought and may have been detected only by chance as a result of closer study of samples rich in shards of dominantly felsic composition. Since the depositional processes of the two types of shards should be independent of each other, sideromelane shards should be just as common in entirely nonvolcanic sediments as in those rich in rhyolitic shards. Dissolution features are generally not severe in the glass shards in the size range studied. However, smaller shards are likely to be more strongly altered because of their larger surface area. Elements released during alteration may significantly influence the composition of pore solutions and mineral phases precipitated from these.

\section{ACKNOWLEDGMENTS}

This work was supported by the Deutsche Forschungsgemeinschaft, grant Schm 250/26, 28-8). I thank H. W. Hubberten for providing the samples, H. Niephaus for the careful bulk-rock analysis on a small sample, M. Simon and R. Neuser for measuring the refractive indices, and $\mathrm{M}$. Becker for help with the microprobe. H. Friedrichsen and T. Barrett kindly provided a preprint of their paper. P. Borella, J. Honnorez, and J. Natland made many helpful comments on the manuscript.

\section{REFERENCES}

Barrett, T. J., and Friedrichsen, H., in press. Elemental and isotopic composition of some metalliferous and pelagic sediments from the Galapagos mounds area, DSDP Leg 70. Chem. Geol.

Bowles, F. A., Jack, R. N., and Carmichael, I. S. E., 1973. Investigation of deep-sea volcanic ash layers from Equatorial Pacific Cores. Geol. Soc. Am. Bull., 84:2371-2388.

Flower, M. F. J., Pritchard, R. G., Schmincke, H. -U., and Robinson, P. T., in press. Geochemistry of basalts: DSDP Sites 482,483 , and 485 near the Tamayo Fracture Zone, Gulf of California. In Lewis, 
B. T. R., Robinson, P., et al., Init. Repts. DSDP, 65: Washington (U.S. Govt. Printing Office).

Honnorez, J., Von Herzen, R. P., Barrett, T. J., Becker, K., Bender, M. L., Borella, P. E., Hubberten, H. -W., Jones, S. C., Karato, S., Laverne, C., Levi, P., Migdisov, G., Moorby, S. A., Schrader, E. L., et al, 1981. Hydrothermal mounds and young crust of the Galapagos: Preliminary Deep Sea Drilling results, Leg 70. Geol. Soc. Am. Bull., 92:457-472.

Lonsdale, P., 1977. Deep-tow observations at the mounds abyssal hydrothermal field, Galapagos Rift. Earth Planet. Sci. Lett., 36: 92-110.

McBirney, A. R., and Williams, H., 1969. Geology and petrology of the Galapagos Islands. Geol. Soc. Am. Mem., 118:1-197.

Natland, J. H., 1980. Effect of axial chambers beneath spreading centers on the compositions of basaltic rocks. In Rosendahl, B. R., Hekinian, R., et al., Init. Repts. DSDP, 54: Washington (U.S. Govt. Printing Office), 333-350.

Natland, J. H., and Melson, W. G., 1980. Compositions of basaltic glasses from the East Pacific rise and Siqueiros fracture zone, near $9^{\circ}$ N. In Rosendahl, B. R., Hekinian, R., et al., Init. Repts. $D S D P$, 54: Washington (U.S. Govt. Printing Office), 705-723.

Ninkovich, D., and Shackleton, N. J., 1975. Distribution, stratigraphic position and age of ash layer " $L$," in the Panama Basin Region, Earth Planet. Sci. Lett., 27:20-34.

Scheidegger, K. F., 1973. Volcanic ash layers in deep-sea sediments and their petrological significance, Earth Planet Sci. Lett., 17: 397-407.
Scheidegger, K. F., Jezek, P. A., and Shackleton, D., 1978. Chemical and optical studies of glass shards in Pleistocene and Pliocene ash layers from DSDP Site 192, Northwest Pacific Ocean. $J$. Volcanol. Geotherm. Res., 4:99-116.

Schmincke, H.-U., 1981. Ash from vitric muds in deep sea cores from the Mariana Trough and Fore-Arc Region (South Philippine Sea) (Sites 453, 454, 455, 458, 459 and SP), Deep Sea Drilling Project, Leg 60. In Hussong, D. M., Uyeda, S., et al., Init. Repts. DSDP, 60: Washington (U.S. Govt. Printing Office), 473-481.

, in press. Ash layers, hyaloclastite and alteration of basalt glass, Leg 65 (Mouth of the Gulf of California). In Lewis, B. T. R., Robinson, P., et al., Init. Repts. DSDP: Washington (U.S. Govt. Printing Office).

Schmincke, H.-U., Robinson, P. T., Ohnmacht, W., Flower, M. J. F., 1978. Basaltic hyaloclastites from Hole 396B, DSDP Leg 46. In Dmitriev, L., Heirtzler, J., et al., Init. Repts. DSDP: Washington (U.S. Govt. Printing Office), 341-346.

Shipboard Scientific Party, in press a. Site 510. In Honnorez, J., Von Herzen, R. P., et al., Init. Repts. DSDP, 70: Washington (U.S. Govt. Printing Office).

, in press b. Site 506. In Honnorez, J., Von Herzen, R. P., et al., Init. Repts. DSDP, 70: Washington (U.S. Govt. Printing Office).

in press c. Site 507. In Honnorez, J., Von Herzen, R. P., et al., Init. Repts. DSDP, 70: Washington (U.S. Govt. Printing Office). 